\title{
Genomic Insights Into Antibiotic Resistance Pattern of Tetracycline Degrading Bacterium Arthrobacter Nicotianae 0TC-16
}

Xin Zhang ( $\nabla$ zhangxins@126.com)

Zhejiang A \& F University

Rongrong Zhu

Zhejiang A \& F University

Weilin Li

Zhejiang A \& F University

Junwei Ma

ZheJiang Academy of Agricultural Sciences

Hui Lin

ZheJiang Academy of Agricultural Sciences

\section{Research Article}

Keywords: antibiotic degrading bacteria, antibiotic resistance genes, Genome

Posted Date: April 12th, 2021

DOI: https://doi.org/10.21203/rs.3.rs-381940/v1

License: (9) This work is licensed under a Creative Commons Attribution 4.0 International License. Read Full License

Version of Record: A version of this preprint was published at Scientific Reports on August 2nd, 2021. See the published version at https://doi.org/10.1038/s41598-021-94840-y. 
1 Genomic insights into antibiotic resistance pattern of

2 tetracycline-degrading bacterium Arthrobacter nicotianae OTC-16

3 Xin Zhang, ${ }^{\mathrm{a}, \#, *}$, Rongrong Zhu ${ }^{\mathrm{a}, \mathrm{b}, \#}$, Weilin $\mathrm{Li}^{\mathrm{a}, \mathrm{b}}$, Junwei Ma ${ }^{\mathrm{b}}$, Hui Lin ${ }^{\mathrm{b}, *}$,

$4 \quad{ }^{a}$ College of Forest and Biotechnology, Zhejiang A \& F University, Hangzhou 311300,

$5 \quad$ China

$6 \quad{ }^{b}$ The Institute of Environment, Resources, Soil and Fertilizers, Zhejiang Academy of

7 Agricultural Sciences, Hangzhou 310021, China

$8 \quad$ \# Equal contributions thus sharing first authorship.

9 * Corresponding authors: College of Forest and Biotechnology, Zhejiang A \& F

10 University, E-mail address: zhangxins@126.com (X. Zhang); The Institute of

11 Environment, Resources, Soil and Fertilizers, Zhejiang Academy of Agricultural

12 Sciences, Tel: +86-571-86404302, Fax: +86-571-86404302, E-mail address:

13 linhui@zaas.ac.cn (H. Lin)

14 Rongrong Zhu (734632819@qq.com)

15 Weilin Li (1520484985@qq.com)

16 Junwei Ma (majw@zaas.ac.cn) 


\section{Abstract}

Although many bacteria have the potential to remove antibiotic residues from environmental niches, the benefits of using antibiotic-degrading bacteria to manage antibiotic pollution should be assessed against the risk of the potential expansion of antimicrobial resistance. This study investigated the antibiotic resistance pattern of the bacterium Arthrobacter nicotianae OTC-16, which shows substantial biodegradation of oxytetracycline/tetracycline. The results showed that this strain could be resistant to at least seven categories, 15 antibiotics, based on antimicrobial susceptibility testing. The genome of $A$. nicotianae OTC-16 contains one chromosome $(3,643,989 \mathrm{bp})$ and two plasmids (plasmid1,123,894 bp and plasmid2, 29,841bp). Of the 3,561 genes isolated, eight were related to antibiotic resistance. During oxytetracycline (OTC) degradation by the strain OTC-16, the expression of ant $2 \mathrm{ia}$, sull, tet33, and cml_e8 in the plasmid, and one gene(tet $V)$ in the chromosome were tracked by real-time quantitative reverse transcription polymerase chain reaction(qRT-PCR). Only the plasmid-derived resistance genes were up-regulated under the pressure of OTC. The presence of OTC increased the tolerance of strain OTC-16 to streptomycin sulphate. This work deepens our understanding of the behavioural characteristics of resistance genes and adaptive evolution of resistant-drug bacteria under the pressure of antibiotics.

Keywords antibiotic-degrading bacteria; antibiotic resistance genes; Genome

\section{Introduction}

Antibiotics have received global attention for their wide application in human 
therapy and livestock agriculture and their widely occurrence in terrestrial and aquatic environments $^{1,2}$, with the evidence leading to a measurable increase in antibiotic resistance genes (ARGs) and the potential to spread to the clinic. Environmental bacteria can utilize antibiotics as carbon or nitrogen sources. For example, there are specific antibiotic-degrading bacteria for $\beta$-lactams ${ }^{3}$, tetracyclines ${ }^{4}$ and sulphonamides ${ }^{5}$. These antibiotic-degrading bacteria have the potential to be developed for bioaugmentation/bioremediation of antibiotic-contaminated environments $^{3,4}$ such as soils near pharmaceutical manufacturers, pharmaceutical wastewater, or livestock manure ${ }^{6}$. However, most of the bioaugmentation/ bioremediation agents were applied to facilitate the removal of antibiotics at fixed-point sites, such as wastewater plants. One important reason for limiting the widespread use of biodegrading agents is that the strains are ecologically risky. Even after the death of the bioaugmentation agents, the naked DNA carrying the ARGs may exist for a long time, thus endangering human health through various pathways such as direct contact or pollution of the food chain ${ }^{7}$. In addition, the horizontal exchange of ARGs through mobile genetic elements such as integrons, plasmids, and transposons would increase resistance rapidly in many indigenous environmental bacteria as a result of exposure to resistant strains ${ }^{8,9}$. Due to these high ecological risks, the World Health Organization has listed ARGs as one of the most important challenges threatening human health in the 21 st century. Therefore, characterisation of the antibiotic resistance profile of these microbial inoculants is an essential step to assess the ecological risks before their application, which could guarantee their safe 
use.

We previously isolated a tetracycline antibiotic-degrading bacterium Arthrobacter nicotianae OTC-16, which shows striking biodegradation of oxytetracycline/tetracycline in various matrices, for example, aqueous media under a wide range of $\mathrm{pH}$, temperature, and antibiotic concentration; manure samples from different animals; and soils with different properties ${ }^{10}$. Preliminary analysis showed that the application of strain OTC-16 did not increase some commonly studied tetracycline-resistant genes in the soil such as tet $W$, tet $B$, tet $A$, and $\operatorname{tet} G$, and could effectively inhibit the proliferation of tet $W$ and tetB. Nonetheless, these results are insufficient to conclude that there is no risk in applying this degrading bacterium in the environment. This study focused on the antibiotic resistance of A. nicotianae OTC-16, with the aim of providing a theoretical basis for the safe use of a degrading strain and further engineering modification to decrease its ecological risk. The influence of the combined use of different drugs on the growth of the degrading strain OTC-16, was also explored. The findings of this study will deepen our understanding of the resistance pattern of the strain and elucidate the role of ARGs in antibiotic resistance and adaptive evolution under the pressure of antibiotics, as well as provide a theoretical basis for the safe use of degrading strains in the future.

\section{Results and discussion}

\section{Antimicrobial susceptibility analysis}


Arthrobacter nicotianae OTC-16 was previously isolated for its efficient biodegradation of OTC and tetracycline, indicating that the strain was resistant to these two antibiotics. Antimicrobial susceptibility testing further confirmed that strain OTC-16 also exhibited obvious resistance to 13 other tested antibiotics, namely, sulfamethoxine, sulfamethoxazole, sulfamethazine, sulfamonomethoxine, cotrimoxazole, bacitracin, streptomycin, streptomycin sulphate, nalidixic acid, nystatin, furazolidone, isopropyl-b-D-thiogalactoside and metronidazole. In addition, strain OTC-16 showed low resistance to chloramphenicol, vancomycin, macrodantin, polymyxin, and kanamycin (Table 2). Overall, strain OTC-16 showed multiple resistance to antimicrobial agents, which might be related to its powerful enzyme systems for decomposing heterogeneous compounds ${ }^{11-15}$.

\section{Genomic features of $A$. nicotianae $\mathrm{OTC}-16$}

The whole genome of the newly isolated A. nicotianae OTC-16 was sequenced (accession number NZ_CP 033 081). Briefly, A. nicotianae OTC-16 contained one chromosome with a total length of 3,643,989 bp and two plasmids with lengths of $123,894 \mathrm{bp}$ and 29,841 bp, spectively (Figure 1); the GC-content of the genome was $61.71 \%$. This genome contained 3,561 genes, including 67 tRNA, 19 rRNA, and 28 sRNA, with a total length of 379,7724 bp. Figure S1 shows detailed GO functional information, from which three main functional domains were established: (i) cellular component, (ii) molecular function, and (iii)biological process. A total of 3,429 genes were annotated related to biological processes; 1,326 genes participated in metabolic processes, 992 genes functioned in cellular processes, and 132 genes responded to 
stimuli. The statistics of KEGG annotation showed that genes of strain OTC-16 can be classified into six categories, with 30 genes related to biosynthesis of secondary metabolites, 12 genes participating in infectious diseases, 68 genes involved in xenobiotics biodegradation and metabolism, and 16 genes related to drug resistance (Figure 2). These drug resistance genes may contribute to the wide resistance of strain OTC-16 to antimicrobials.

The ARGs were obtained by CARD analysis, and detailed information is listed in Table 3. Briefly, eight antibiotic resistance types, a total of 23 copies of ARGs of strain OTC-16 were recognised and most of them, with four types (sull, tet33, ant2ia, and cml_e8), 15 copies of ARGs located in plasmids. Cells of strain OTC-16 grew well when exposed to all the possible antibiotics encoded by the ARGs, as was observed in antimicrobial susceptibility testing. Tetracycline resistance involved tet33 in both plasmid I and plasmid II, and tet $V$ in the chromosome. Genes tet $V$ and tet33 encode efflux proteins, known as membrane-associated proteins, that export tetracyclines from the cell. The export of tetracyclines reduces intracellular drug concentration, and therefore, protects the ribosome within the cell. This may be the reason why strain OTC-16 grew well under the pressure of tetracycline and oxytetracycline. Since the tet genes were unable to decompose tetracycline antibiotics, the role of these genes in strain OTC-16 during tetracycline degradation should be considered in the future. The gene ant2ia encodes aminoglycoside transferases, which inactivate aminoglycosides and confer resistance to aminoglycoside antibiotics ${ }^{16}$. In antimicrobial susceptibility testing, strain OTC-16 showed high-resistance to 
streptomycin and medium-resistance to tobramycin and kanamycin. The genes sull and $c m l \_e 8$ provided strain resistance to sulfonamides and chloramphenicol, respectively. The antibiotic resistance spectrum experiment in this work also confirmed the existence and function of these ARGs. Strain OTC-16 grew well when facing sulfadimethazine, sulfamethoxazole, sulfamonomethoxine, and cotrimoxazole, and showed tolerance to chloramphenicol to some extent.

A total of three A. nicotianae strains have been sequenced to date. Strain ZM05 (accession number NZ_CP059853.1) has only one plasmid (accession number NZ_CP059854.1) and strain NBRC14234 (accession number

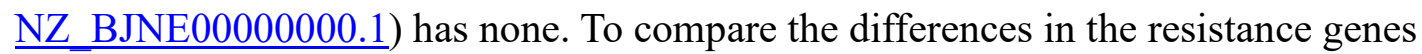
carried by the three strains, the ARGs listed in Table 3 were used as target genes to BLAST among the three strains with the NCBI software. BLAST results showed that the ARGs contained in the three strains differed. Although the ARGs were mostly located in plasmids in strain OTC-16, they all existed on chromosomes in strains ZM05 and NBRC14234. Strain ZM05 shared seven single-copy homologous resistance genes with strain OTC-16, the gene with the highest homology is vanre, with an identity value of $100 \%$, followed by genes vanrc $(99.41 \%)$ and cara $(99.24 \%)$. While strain NBRC14234 had fewer ARGs, only the single copy genes, bcra and ctab3, were detected, and the homology was also lower than that of strain ZM05(Table S1). Other detailed information can be found in the Supplementary Information. Comparison of the sequences of the three strains confirmed that the evolution of ARGs of the same bacterial species in different regions was different. 
Common ARGs are more likely to evolve in similar and immediate surroundings. In this study, strains OTC-16 and ZM05 were both from China; they share 7 common ARGs. Meanwhile, strain NBRC14234, isolated from Japan, has only two low homologous common ARGs with strain OTC-16. Therefore, ARGs carried by strains reflected the evolution of the strain in the environment, and also possibly reflected the antibiotic pollution level where the strains survive.

Plasmids with ARGs replicated independently in cells, and can transfer to other bacteria through transformation and conjugation, leading to gene transport and diffusion. While in those strains with ARGs distributed on chromosomes, such as strains ZM05 and NBRC14234; the transmission of ARGs may be mainly achieved by transposition.

\section{Expression of ARGs in OTC-16 under OTC stress}

To study the expression characteristics of ARGs at different genetic loci, the behaviour of sull, tet33, ant2ia, and $\mathrm{cml} e 8$, located in plasmids and gene tet $V$ carried by chromosomes, were tracked by qRT-PCR. The results showed that all five resistant genes could be expressed in strain OTC-16 with or without exposure to OTC. The expression levels of these genes increased at first and then decreased during incubation; however, the peak time was slightly different (Figure 3). Thus, the five tested ARGs were identified as constitutively expressed genes, which were automatically expressed with the growth of bacteria regardless of resistant stress. However, the expression levels of these genes were significantly different. Expression of gene ant2ia was dominant, and its relative expression value was approximately 10 
times that of genes tet33 and sull, 1,000 times that of tet $V$, and $10^{5}$ times that of cml_e8. Overall, genes ant2ia, tet33, and sull were more active in strain OTC-16 than genes tet $V$ and $\mathrm{cml}$ e8. The antibiotic resistance spectrum experiment in this work confirmed the existence and expression of these ARGs. Strain OTC-16 could grow well when facing streptomycin, tetracycline, oxytetracycline, sulfadimethazine, and sulfamethoxazole. However, the appearance of chloramphenicol inhibited cell proliferation of this strain, possibly because of the low expression of gene $c m l \_8$.

Figure 4 indicates that the presence of OTC generally suppressed the expression of genes $c m l \_e 8$ and tet $\mathrm{V}$, but significantly promoted the relative expression of genes ant2ia, sul1, and tet33 during early culture ( 0 to $48 \mathrm{~h})$. The maximum upregulated expression occurred at $24 \mathrm{~h}$ for gene tet33, and $48 \mathrm{~h}$ for genes ant2ia and sul1; however, they all declined sharply $72 \mathrm{~h}$ later. The expression of genes ant2ia and sull at $168 \mathrm{~h}$ in OTC treatments was even lower than that in the controls. Overall, OTC evidently up-regulated the expression of these ARGs, but it is a short-term effect. The up-regulation of genes sull and ant2ia by OTC (Figure 4) implied that the presence of OTC improved the resistance of strain OTC-16 to antibiotics encoded by these genes. The hypothesis was tested by the experiment shown in Figure 5, in which the growth of A. nicotianae OTC-16 in different antibiotic treatments is shown. It was found that the cell growth of strain OTC-16 in the presence of streptomycin sulphate improved after the addition of OTC at a concentration of $100 \mathrm{mg} \cdot \mathrm{L}^{-1}$. In contrast, the co-existence of sulfamethoxazole and OTC resulted in lower cell growth of strain OTC-16 than the individual antibiotic. However, the adverse effect of the co-existence 
of sulfamethoxazole and OTC was alleviated at $36 \mathrm{~h}$, which was supposed to be related to the up-regulation of sullgene expression. Gao found that tetracycline stress can promote the transcriptional expression of tetracycline-related ARGs of Shigella flexneri ${ }^{17}$. Our study showed that the presence of OTC could also activate other ARGs of strain OTC-16 not related to OTC resistance, such as the sulphonamide resistance gene sull and aminoglycoside resistance gene ant2ia. However, the resistance of the strain to these antibiotics is not completely improved, and depends on many factors, such as the type of antibiotics and duration.

The synchronised up-regulated expression of genes tet33, sull, and ant2ia indicated that the three ARGs may have a synergistic regulation mechanism. Synergistic regulation refers to the process in which a series of transcription and translation systems of bacteria respond simultaneously to any kind of environmental pressure, such as antibiotics and heavy metals ${ }^{18}$. Through this mechanism, the addition of OTC can reduce the sensitivity of strain OTC-16 to other antibiotics. A similar phenomenon has been reported for heavy metals; for example, copper and zinc ions could coordinate the regulation of antibiotic resistance genes and enhance bacterial tolerance to chloramphenicol, tetracycline, thiomycin, and other antibiotics ${ }^{19-21}$. In addition, similar fluctuation trends and the synchronous transcription phenomenon among the three ARGs suggested that they may have relatively close genetic loci or maybe regulated by the same or similar regulatory proteins. Analysing and mapping the gene drafts of strain OTC-16 showed that ant2ia, sull, and tet33 were all multiple copy genes, and these genes were closely connected in position and formed tandem 
repeat tet33-sul1-ant2ia gene series located exclusively in plasmids 1 and 2 . In addition, constant spacer regions of 4625 bp were observed between genes tet 33 and sull, of 418 bp between genes sulland ant2ia, and of 1492 bp between genes ant2ia and tet33 (Figure 6). Based on the expression pattern and gene location, we speculated that these three genes may be in a resistance chain transmission vector, such as transposon and integron, and could be transferred horizontally ${ }^{22}$. Integrons are genetic entities that are defined by their ability to capture members of a large family of small mobile elements known as 'gene cassettes'. Gene cassettes can be incorporated into a specific site of integrons by a site-specific recombinase encoded by the gene $\operatorname{intI}^{23}$. To verify our speculation, the sequence of gene intI was examined in the plasmids of strain OTC-16. Finally, a total of 10 copies of gene intI, mostly with a constant sequence region (764 bp), were recognised. All genes were located adjacent to the ARGs in above mentioned cassettes; four were located in plasmid 1 and six in plasmid 2 (Figure 6). Integrons are a common genetic element involved in the development of multiple antibiotic resistance and play vital roles in improving the potential of bacteria to adapt to the surrounding environments ${ }^{24,25}$. The survival of bacteria sometimes depends on their ability to capture integrons and transferability of the same plasmid ${ }^{24}$. In this respect, integrons are products of the evolution of bacteria. Plasmid-derived ARGs (ant2ia, sul1, and tet33) were greatly induced by external addition of OTC and had obviously higher expression activity compared with genes carried by chromosomes (tetV). The results are consistent with the report by Qin ${ }^{16}$, who claimed that genes associated with mobile genetic elements generally showed 
higher levels of expression under antibiotic-treated conditions than those in chromosomes, based on analysing the transcriptomics of 12 multidrug-resistant Acinetobacter baumannii. The proposition was further verified by $\mathrm{Liu}^{26}$, who conducted metagenome and macro-transcriptome analysis on sludge and found that ARGs with high transcription abundance are mainly related to plasmid-derived resistance genes. We proposed that the tetracycline-specific efflux pump gene tet33 of the major facilitator super family (MFS) on the plasmids maybe an important genetic element for strain OTC-16 to resist OTC; however, its role in the degradation process of OTC still needs to be further verified. The inherent ARGs improve the resistance of the degrading strain to various antibiotics and enhance its adaptability to the environment when the host bacterium was applied as bioaugmentation/biodegradation agent. However, the presence of these genes also increases the risk of the expansion of antimicrobial resistance, especially those located in mobile genetic elements such as plasmids and integrons, just like genes ant2ia, sull, and tet33 in this work. Actually, plasmid conjugation is one of the dominant mechanisms of horizontal gene transfer ${ }^{27,28}$, contributing to the increasing resistance of indigenous bacteria. A recent study showed that a conjugative antibiotic resistance plasmid, RP4, harboured by the donor strain Pseudomonas putida KT2442 could be disseminated to bacteria affiliated with more than 15 phyla $^{29}$. Therefore, from this point of view, strain OTC-16 may currently pose a high ecological threat, mainly due to the resistance plasmids. However, despite the ecological risks, one cannot deny the significant application prospects of the strain. In contrast, the expression behaviour of the resistant genes in 
this study provides some inspiration for genetic modification of the strain. Since most resistance genes are located on plasmids, a strategy capable of bypassing the development of resistance by shearing redundant resistance genes on plasmids and even directly eliminating plasmids could be adopted in the future to reduce the proliferation and spread of resistance genes in the environment.

\section{Conclusions}

Many ARGs unrelated to tetracycline degradation were identified in an efficient oxytetracycline/tetracycline-degrading bacterium A. nicotianae OTC-16, which make the strain resistant to at least seven categories, 15 antibiotics. Actively expressed genes, such as ant2ia, sul1, andtet33, are mostly located in plasmids and are incorporated into integrons as 'gene cassettes' with obvious mobile characteristics. This study provides valuable information for improved and safe application of this strain and insights to reducing its ecological risk by genetic modification. These findings deepen our understanding of the ecological role and adaptive evolution of antibiotic-degrading microorganisms in the environment.

\section{Materials and methods}

\section{Strain and medium}

The OTC-degrading strain A.nicotianae OTC-16, used in this study, was previously isolated from active sludge around a pharmaceutical factory in Taizhou, Zhejiang province, China. Luria-Bertani (LB) medium ( $\mathrm{pH} 7.2)$ containing $10 \mathrm{~g} \cdot \mathrm{L}^{-1}$ tryptone, $5 \mathrm{~g} \cdot \mathrm{L}^{-1}$ yeast extract, and $10 \mathrm{~g} \cdot \mathrm{L}^{-1} \mathrm{NaCl}$, was used for incubation of the strain. The kits used in this study included the Axygen ${ }^{\circledR}$ AxyPrep Plasmid Miniprep 
Kit, RNAiso plus Kit (Takara®Biochemicals, Hangzhou, China), TRANS DNA extraction kit (TransGen Biotech, Beijing, China), PrimeScript ${ }^{\mathrm{TM}}$ RT reagent Kit with gDNAEraser (Perfect Real Time, Takara Biochemicals, Hangzhou, China), MightyAmp for Real Time (TB Green Plus; Takara Biochemicals, Hangzhou, China), and Omega EZNATM soil DNA Kit (Omega Bio-Tek, Inc, USA).

\section{Antimicrobial susceptibility testing}

Susceptibility of the OTC-16 strain to drugs was determined using antibiotic discs ( $\mu$ g per disc, unless indicated). A single colony of strain OTC-16 was inoculated into LB liquid medium, and $80 \mu \mathrm{L}$ of bacterial suspension was spread evenly on LB solid medium in petri dishes. Discs soaked with antibiotics were then placed in these plates. The inhibitory effects of antibiotics on strain OTC-16 were assessed after $24 \mathrm{~h}$ by measuring the diameter of the bacteriostatic circle of each disc. Absence of a bacteriostatic circle indicated that the strain was highly resistant to the target drug; appearance of an obvious bacteriostatic circle $($ diameter $\geq 1.3 \mathrm{~cm})$ indicated that the strain was sensitive to the antibiotic; and when the diameter of bacteriostatic circle was less than $1.3 \mathrm{~cm}$, the strain was deemed to have medium-resistance to the drug. The experiment was performed in triplicate for each drug, with a total of 52 commonly used antibiotics tested. The antibiotics tested in this experiment were purchased from Solarbio (Beijing, China) with a purity $\geq 99 \%$.

\section{Whole-genome sequencing}

Arthrobacter nicotianae OTC-16 was cultivated aerobically at $30^{\circ} \mathrm{C}$ for $24 \mathrm{~h}$ in LB medium. DNA extraction was conducted using the TRANS DNA extraction kit 
according to the manufacturer's protocol. The genome of $A$. nicotianae OTC-16 was sequenced using a PacBio RS II platform and Illumina HiSeq 4000 platform at the Beijing Genomics Institute (BGI, Shenzhen, China). The tRNAs and rRNAs were identified using tRNAscan-SE ${ }^{30}$, RNAmmer ${ }^{31}$ and Rfam databases. The best hit was abstracted using the BLAST alignment tool for function annotation. Seven databases, including KEGG (Kyoto Encyclopedia of Genes and Genomes), COG (Cluster of Orthologous Groups of proteins), NR(Non-Redundant Protein Database), Swiss-Prot, GO (Gene Ontology), TrEMBL (Translation of European Molecular Biology Laboratory) and EggNOG (Evolutionary Genealogy of Genes: Non-supervised Orthologous Groups) were used for general function annotation. Virulence factors and resistance genes were identified based on the core dataset in VFDB (the Virulence Factors of Pathogenic Bacteria) and CARD (the Comprehensive Antibiotic Research Database).

\section{Quantitative polymerase chain reaction}

Freshly cultured bacterial suspensions with $\mathrm{OD}_{600 \mathrm{~nm}}=1.8$ were inoculated into treatment (LB broth spiked with $100 \mathrm{mg} \cdot \mathrm{L}^{-1} \mathrm{OTC}$, hereafter referred to as $\mathrm{LB}^{\mathrm{R}}$ broth) and control (LB broth only) at a dose of $3 \%(\mathrm{v} / \mathrm{v})$ and then incubated at $30{ }^{\circ} \mathrm{C}$ for $7 \mathrm{~d}$. The cultures were performed in triplicate, and the bacterial suspensions were sampled every $24 \mathrm{~h}$. Total RNA was extracted using the RNAiso plus Kit. The obtained RNA was dissolved in ribonuclease-free water, and high-quality RNA with purity and concentration which met the PCR standard was saved and used in the subsequent experiments. Approximately $1 \mu \mathrm{g}$ of RNA was used for real-time PCR in 
each sample. Complementary DNA (cDNA) was synthesised using a PrimeScript ${ }^{\mathrm{TM}}$

RT reagent Kit with a gDNAEraser, according to the manufacturer's instructions.

Expression of five antibiotic resistance genes (tet $V$, sull, tet33, ant2ia, and cml_e8) was tracked by real-time qRT-PCR with reference to the whole genome sequence of $A$. nicotianae strain OTC-16 (NZ_CP 033 081). The primers for the candidate genes were designed using the primer analysis software Primer 5.0, and the primer specific verification was performed on the National Center for Biotechnology Information (NCBI). The 16S rRNA V3 region (simply referred to as 16S rRNA) was used in the study as the reference gene for quantitative analysis. Detailed information on the primers is listed in Table 1.

Real-time qRT-PCR was performed with Mighty $\mathrm{Amp}^{\mathrm{TM}}$ for Realtime PCR Kit and conducted on an ABI StepOnePlus Real-Time PCR System (PerkinElmer Applied Biosystems, Foster City, CA, USA). The specificity of the amplified product was confirmed by the melting temperature. With $16 \mathrm{~S}$ rRNA as the internal reference gene, the results of the qRT-PCR were normalised to obtain the relative value of resistance gene expression. The relative value of gene expression and the relative expression of resistance genes were calculated using the following two formulas:

$$
\begin{aligned}
& \text { Relative value of gene expression }=\frac{N 1}{N 2} \\
& \text { Relative expression of resistance gene }=\frac{V T}{V C K}
\end{aligned}
$$

Where $N 1$ denotes the copy number of target gene, $N 2$ denotes the copy number of the 16S rRNA gene, $V T$ denotes the gene expression value of treatment group genes, and $V C T$ denotes the gene expression value of control group genes. 


\section{Response of cell growth to co-existence of multiple antibiotics}

Freshly cultured bacterial suspensions with $\mathrm{OD}_{600 \mathrm{~nm}}=1.8$ were inoculated into 5 $\mathrm{mL}$ of $\mathrm{LB}^{\mathrm{R}}$ broth at a $3 \%(\mathrm{v} / \mathrm{v})$ dose. Streptomycin sulphate and sulfamethoxazole were selected as target antibiotics in this experiment at a final concentration of 100

$\mathrm{mg} \cdot \mathrm{L}^{-1}$. Four groups were designed for each target antibiotic (TA): (1) TA + strain OTC-16; (2) TA +OTC +strain OTC-16; (3) OTC +strain OTC-16; and (4) strain OTC-16 only. The cultures were performed in triplicate, and the $\mathrm{OD}_{600 \mathrm{~nm}}$ values of the bacterial suspension were recorded every $12 \mathrm{~h}$.

\section{References}

1. Kemper, N. Veterinary antibiotics in the aquatic and terrestrial environment. Ecol. Indic. 8 , 1-13 (2007).

2. Yang, Y., Song, W., Lin, H., Wang, W., Du, L. \& Xing, W. Antibiotics and antibiotic resistance genes in global lakes: A review and meta-analysis. Environ. Int. 116, 6073 (2018).

3. Crofts, T. S., et al. Shared strategies for $\beta$-lactam catabolism in the soil microbiome. Nat. Chem. Bio. 14, 556-564 (2018).

4. Leng, Y., et al. Biotransformation of tetracycline by a novel bacterial strain Stenotrophomonas maltophilia DT1. J. Hazard. Mater.318, 125-133 (2016).

5. Ghosh, S., Sadowsky, M.J., Roberts, M.C., Gralnick, J.A., Lapara, T.M. Sphingobacterium sp. strain PM2-P1-29 harbours a functional tet(X) gene encoding for the degradation of tetracycline. J. Appl. Microbiol. 106, 1336-1342 (2010). 
374

375

6. Gros, M., et al. Biodegradation of the X-ray contrast agent iopromide and the fluoroquinolone antibiotic ofloxacin by the white rot fungus Trametes versicolor in hospital wastewaters and identification of degradation products. Water. Res. 60, 228-241 (2014).

7. Crecchio, C., et al. Binding of DNA from Bacillus subtilis on MontmorilloniteHumic Acids-Aluminum or Iron Hydroxypolymers. Soil. Sci. Soc. AM. J. 69, 834-841 (2005).

8. Wright, G. D. Antibiotic resistance in the environment: a link to the clinic? Curr. Opin. Microbiol. 13, 589-594 (2010).

9. Zhang, S., et al. Dissemination of antibiotic resistance genes (ARGs) via integrons in Escherichia coli : A risk to human health. Environ. Pollut. 266, 115260 (2020).

10. Shi, Y., et al. Degradation of tetracycline antibiotics by Arthrobacter nicotianae OTC-16. J. Hazard. Mater. 403, 123996 (2021).

11. Martin, W. \& Friedhelm, M. Replication-involved genes of pAL1, the linear plasmid of Arthrobacter nitroguajacolicus Rü61a--phylogenetic and transcriptional analysis. Plasmid 65, 176-184 (2011).

12. Zhao, X., et al. Complete genome sequence of Arthrobacter sp. ZXY-2 associated with effective atrazine degradation and salt adaptation. J. Biotechnol. 248, 43-47 (2017).

13. Deng, Y., Mao, Y., Li, B., Yang, C. \& Zhang, T. Aerobic Degradation of Sulfadiazine by Arthrobacter spp.: Kinetics, Pathways, and Genomic Characterization. Environ. Sci. Technol. 50, 9566-9575 (2016). 
14. Hu, W., et al. Enhanced degradation of 1-naphthol in landfill leachate using Arthrobacter sp. Environ. Technol. 40, 1-20 (2019).

15. Guo, X., Xie, C., Wang, L., Li, Q.\& Wang, Y. Biodegradation of persistent environmental pollutants by Arthrobacter sp. Environ. Sci. Pollut. Res. 26, 84298443 (2019).

16. Qin, H., et al. Comparative transcriptomics of multidrug-resistant Acinetobacter baumannii in response to antibiotic treatments. Sci. Rep. 8, 3515 (2018).

17. Gao, P., Ruan, X., Qiu,W. Impact of Tetracycline Antibiotic on Transcriptional Expression of Tetracycline Resistance Genes in Shigella flexneri. Environ. Sci. 41, 3758-3764 (2020).

18. Tuckfield, R. C. \& McArthur, J. V. Spatial Analysis of Antibiotic Resistance Along Metal Contaminated Streams. Microb. Ecol. 55, 595-607 (2008).

19. Harrison, J. J., et al. Chromosomal antioxidant genes have metal ion-specific roles as determinants of bacterial metal tolerance. Environ. Microbiol. 11, 2491-2509 (2009).

20. Caille, O., Rossier, C. \& Perron, K. A copper-activated two-component system interacts with zinc and imipenem resistance in Pseudomonas aeruginosa. $J$. Bacteriol. 189, 4561-4568 (2007).

21. Chen, S., et al. Heavy Metal Induced Antibiotic Resistance in Bacterium LSJC7. Int. J. Mol. Sci. 16, 23390-23404 (2015).

22. Zhang, X., Zhang, T., Zhang, M., Fang, H. H. P. \& Cheng, S.-P. Characterization and quantification of class 1 integrons and associated gene cassettes in sewage 
treatment plants. Appl. Microbiol. Biotechnol. 82, 1169-1177 (2009).

419

420

421

422

423

424

425

426

427

428

429

430

431

432

433

434

435

436

437

438

439

23. Messier, N. \& Roy, P. H. Integron integrases possess a unique additional domain necessary for activity. J. Bacteriol. 183, 6699-6706 (2001).

24. Kaushik, M., Kumar, S., Kapoor, R. K., Virdi, J. S. \& Gulati, P. Integrons in Enterobacteriaceae : diversity, distribution and epidemiology. Int. J. Antimicrob. Ag. 51, 167-176 (2018).

25. Marathe, N. P., et al. Sewage effluent from an Indian hospital harbors novel carbapenemases and integron-borne antibiotic resistance genes. Microbiome. 7, 97 (2019).

26. Liu, Z., et al. Metagenomic and metatranscriptomic analyses reveal activity and hosts of antibiotic resistance genes in activated sludge. Environ. Int. 129, 208-220 (2019).

27. Sørensen, S. J., Bailey, M., Hansen, L. H., Kroer, N. \& Wuertz, S. Studying plasmid horizontal transfer in situ : a critical review. Nat. Rev. Microbiol. 3, 700-710 (2005)

28. Thomas, C. M. \& Nielsen, K. M. Mechanisms of, and Barriers to, Horizontal Gene Transfer between Bacteria. Nat. Rev. Microbiol. 3, 711-721 (2005).

29. Fan, X., et al. Fate of Antibiotic Resistant Pseudomonas putida and Broad Host Range Plasmid in Natural Soil Microcosms. Front Microbiol. 10, 194 (2019).

30. Lowe, T. M. \& Eddy, S. R. tRNAscan-SE: a program for improved detection of transfer RNA genes in genomic sequence. Nucleic. Acids. Res. 10,955-964 (1997).

31. Lagesen, K.,et al. RNAmmer: consistent and rapid annotation of ribosomal RNA 

genes. Nucleic. Acids. Res. 9, 3100-3108 (2007).

\section{Acknowledgements}

444 (31970093, 41977328, 31670110).

\section{Author contributions}

446

447

448

449

450

451

452 The authors declare no competing interests.

453

454 


\section{Figure Legends}

456

457

458

459

460

461

462

463

464

465

466

467

468

469

470

Fig. 1 Circular map of the chromosome (a), plasmid1 (b) and plasmid2 (c) of strain

OTC-16. From inner to outer: Genome size; Forward Strand Gene(colored by COG

classification); Reverse Strand Gene(colored by COG classification); Forward Strand

ncRNA; Reverse Strand ncRNA; Repeat gene; G+C content; GC-SKEW(calculated

as $(\mathrm{G}-\mathrm{C}) /(\mathrm{G}+\mathrm{C})$; green/purple peaks out/inside the circle indicate values higher or

lower than 1 , respectively.

Fig. 2 KEGG function annotation distribution map of strain OTC-16.

Fig. 3 Relative abundance of resistance gene expression at 24-168 h.

Fig. 4 The expression levels of resistance genes tet33, sull, and ant2ia changed at 24-168 h.

Fig. 5 Effect of streptomycin sulfate(a) and sulfamethoxazole(b) on the growth of strain OTC-16.

Fig. 6 The sites of gene sul1, tet33 and ant2ia on plasmid 1 and plasmid 2. 
a

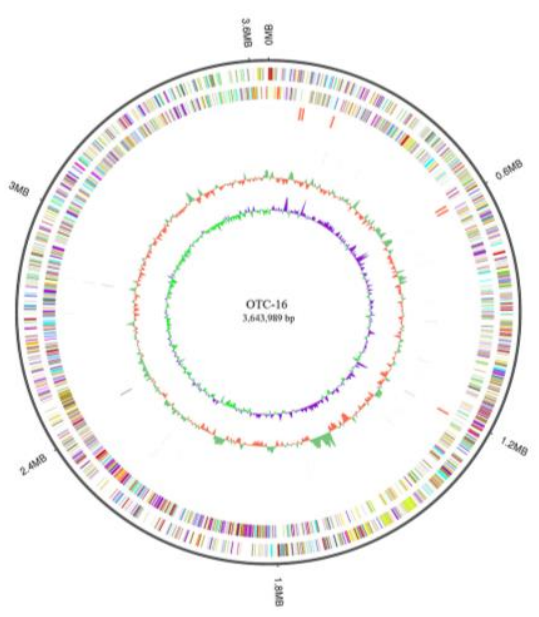

b

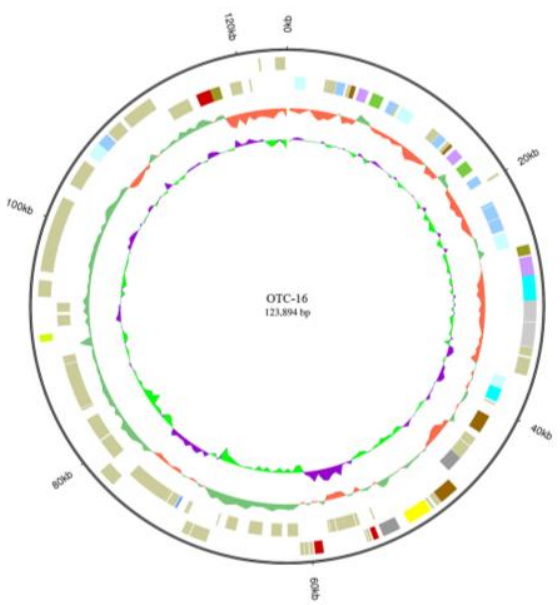

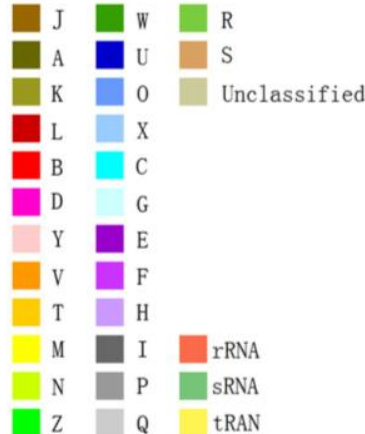

C

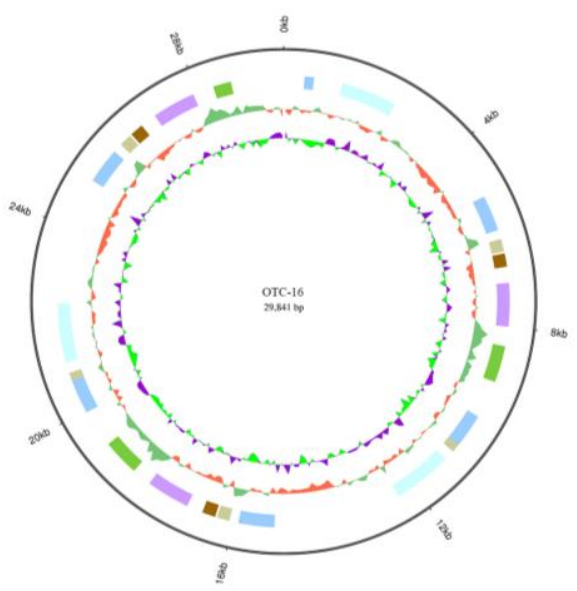

Figure 1 Circular map of the chromosome (a), plasmid1 (b) and plasmid2 (c). From inner to outer: Genome size; Forward Strand Gene(colored by COG classification); Reverse Strand Gene(colored by COG classification); Forward Strand ncRNA; Reverse Strand ncRNA; Repeat gene; G+C content; GC-SKEW(calculated as $(\mathrm{G}-\mathrm{C}) /(\mathrm{G}+\mathrm{C})$; green/purple peaks out/inside the circle indicate values higher or lower than 1 , respectively. 


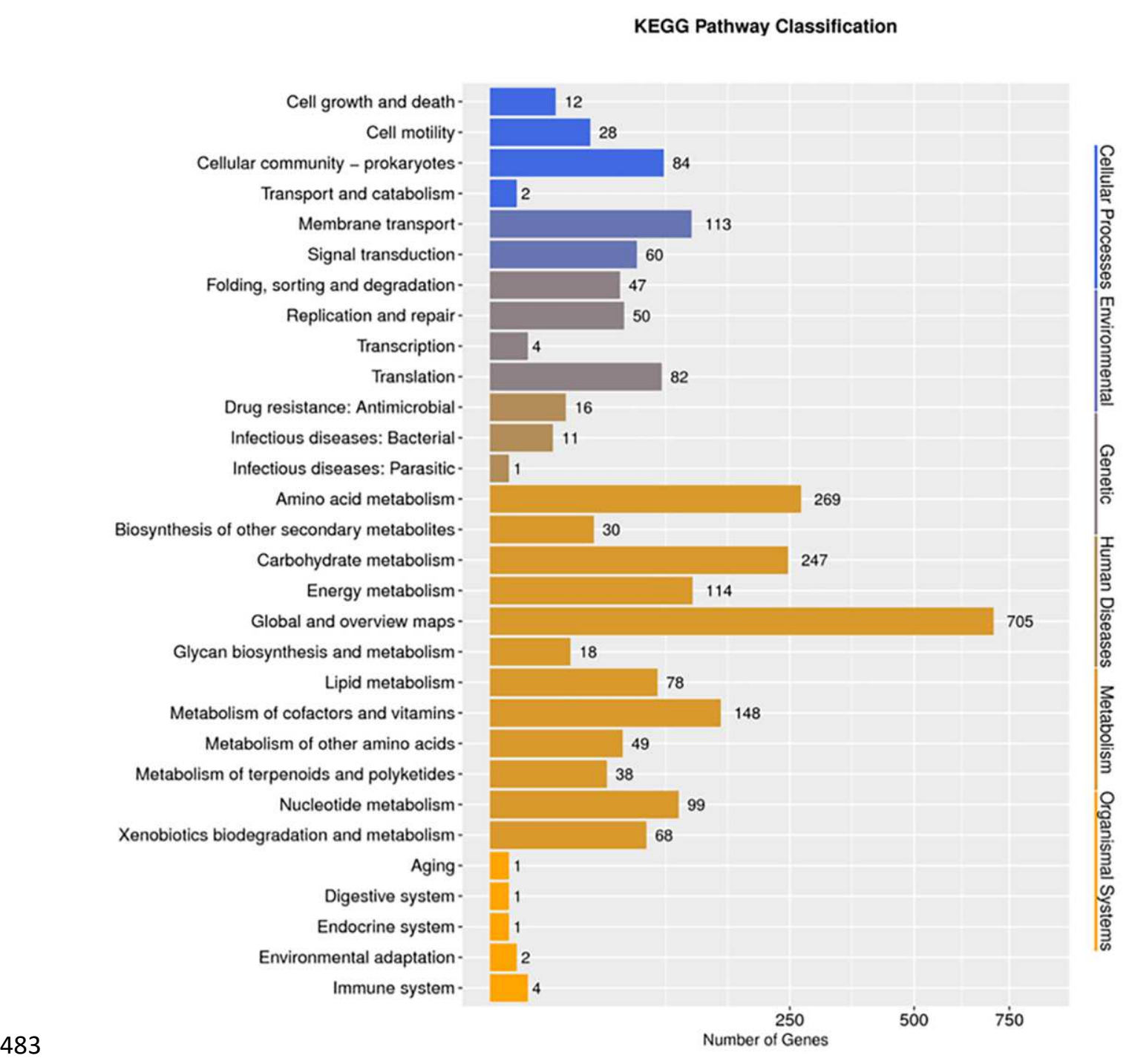



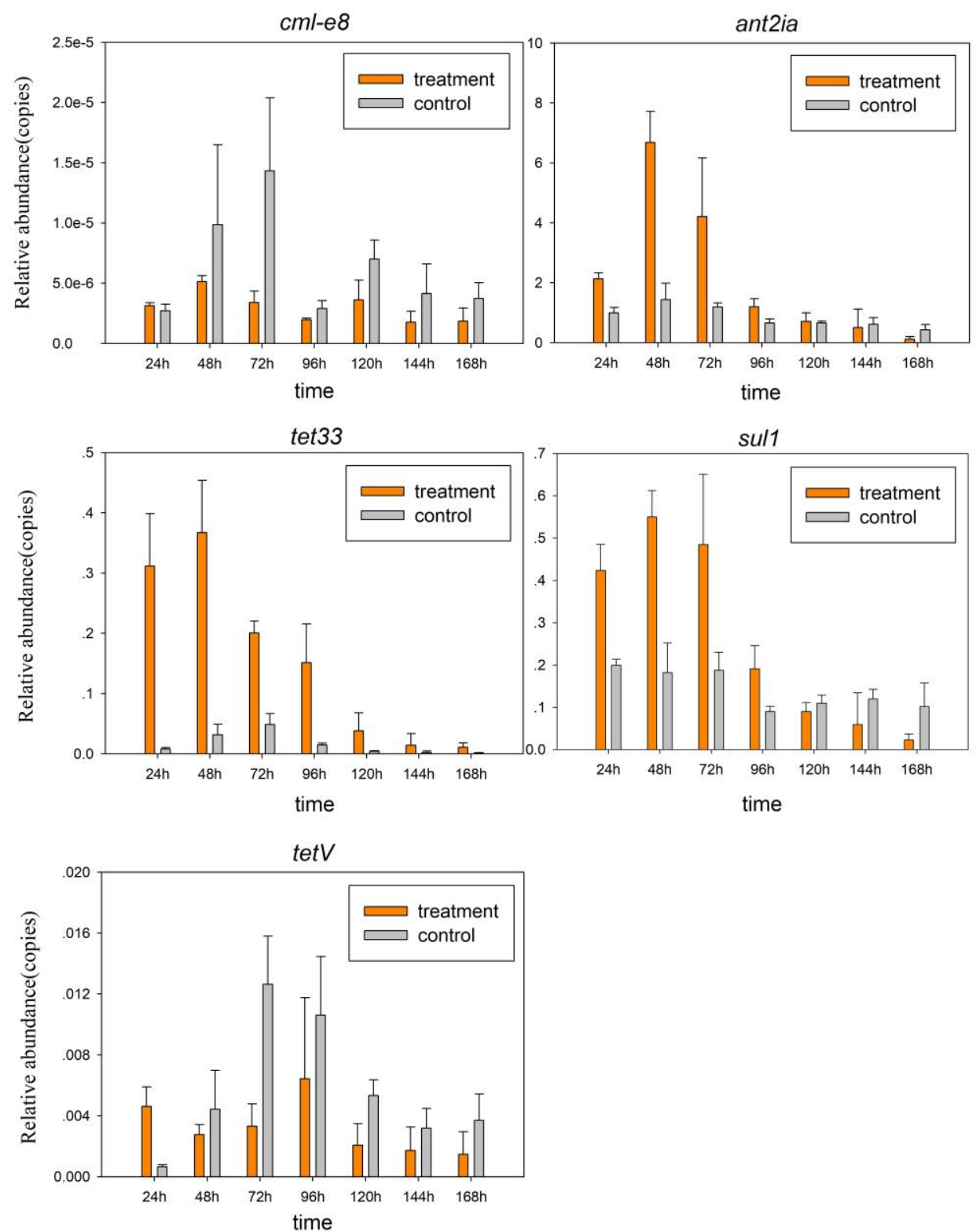

487

Figure 3 Relative abundance of resistance gene expression at 24-168 h 

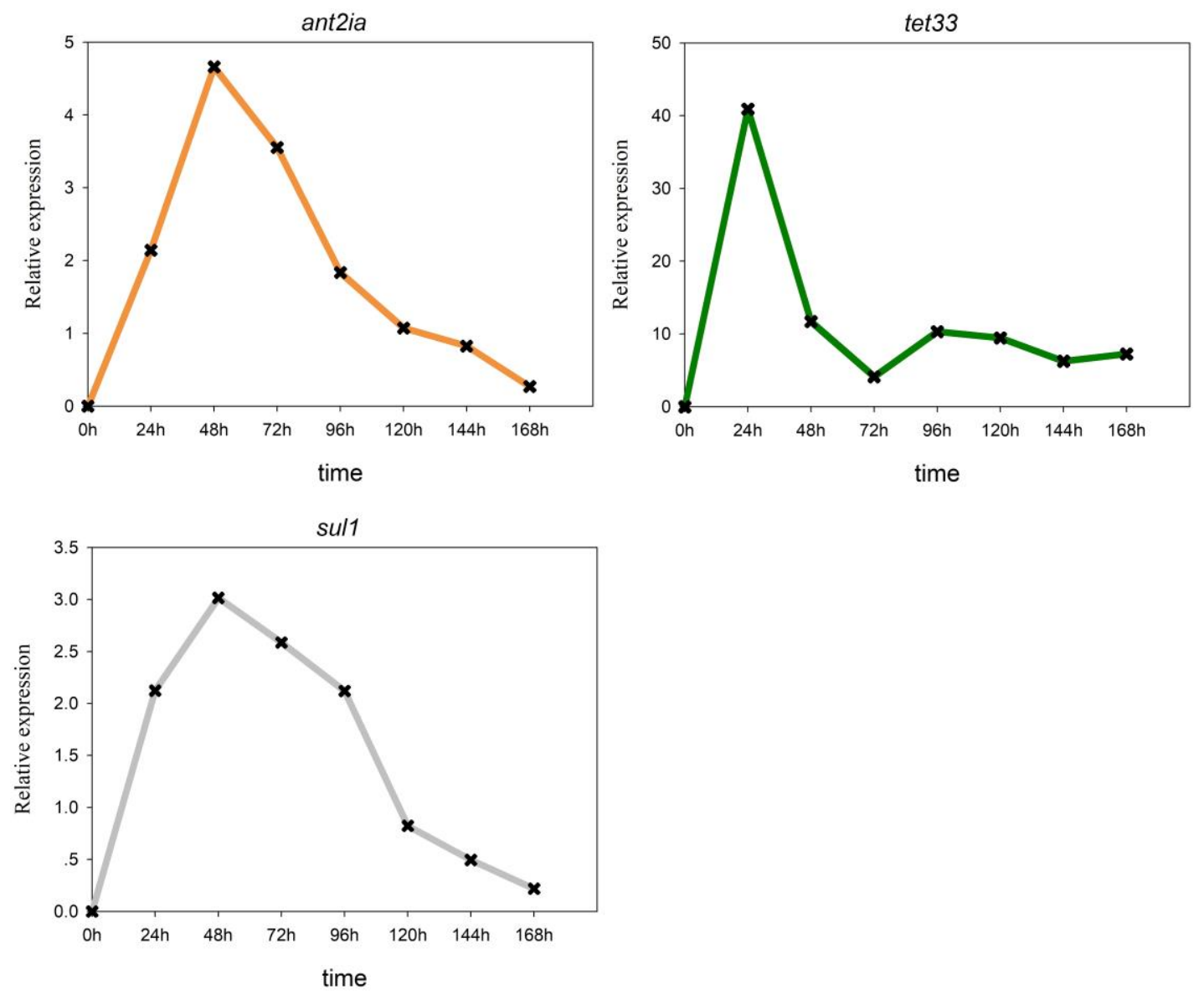

490

491 Figure 4 The expression levels of resistance genes tet33, sull, and ant2ia changed at $492 \quad 24-168 \mathrm{~h}$

493 

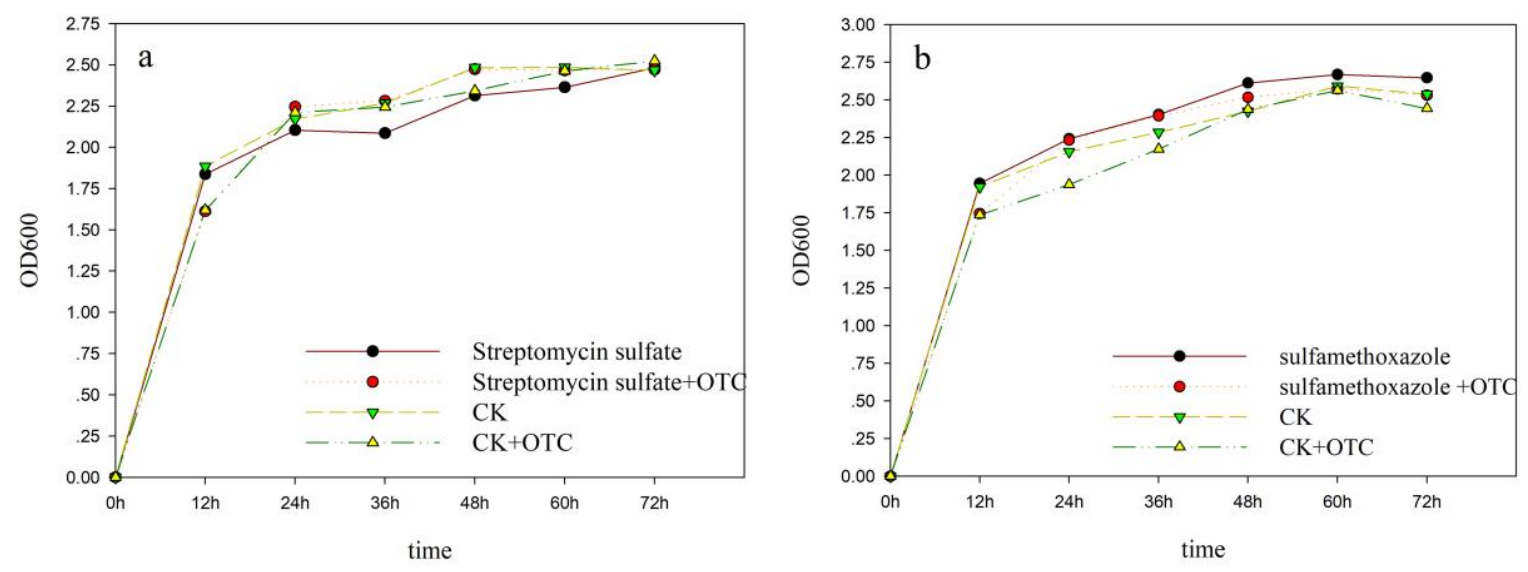

496

497

498

Figure 5 Effect of streptomycin sulfate(a) and sulfamethoxazole(b) on the growth of strain OTC-16

499

500

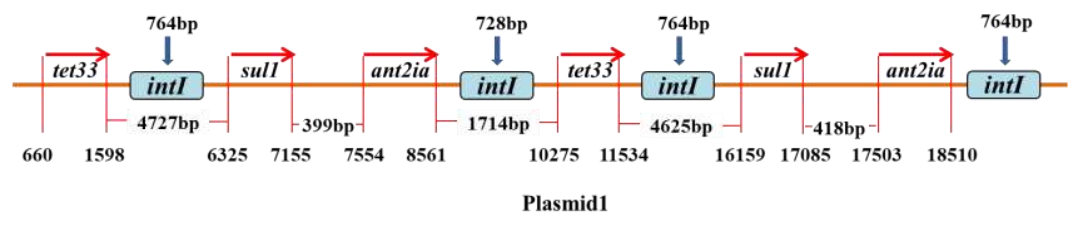

501

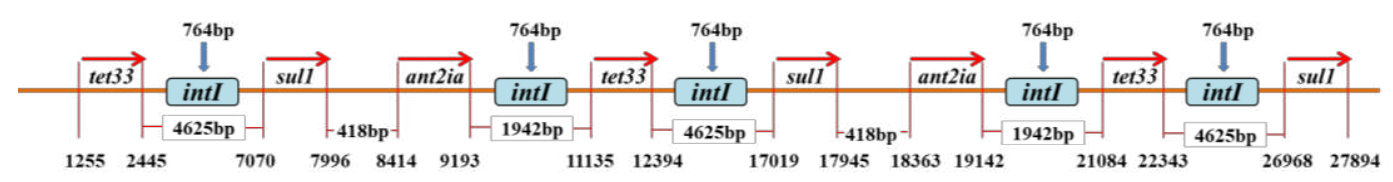

Plasmid2

Figure 6 The sites of gene tet33, sull and ant2ia in plasmid 1 and plasmid 2 
Table 1. Primers and annealing temperatures for qPCR assays

\begin{tabular}{|c|c|c|}
\hline Primer & primer sequence (5'-3') & $\mathbf{T}_{\mathbf{m}}\left({ }^{\circ} \mathbf{C}\right)$ \\
\hline tet $33-F$ & TCCCGCACTGCTACACGA & \multirow{2}{*}{55} \\
\hline tet33-R & GCGAGATGGCACCGAACA & \\
\hline cml_e8-F & CGTGCCAGCGAACCAGAAG & \multirow{2}{*}{55} \\
\hline cml_e8-R & TGGGTGCCAGGAAGGTGAAT & \\
\hline tet $V-F$ & GCACTCGTCTTCTCCACCTT & \multirow{2}{*}{55} \\
\hline tet $V-R$ & GGTTCCCTCCAGCCCATTAG & \\
\hline ant $2 i a-F$ & CATCCCGTGGCGTTATCC & \multirow{2}{*}{55} \\
\hline ant $2 i a-R$ & CTGGGCAGGTAGGCGTTT & \\
\hline sull-F & CGCACCGGAAACATCGCTGCAC & \multirow{2}{*}{65} \\
\hline sull-R & TGAAGTTCCGCCGCAAGGCTCG & \\
\hline $16 S$ rRNA-F & CCTACGGGAGGCAGCAG & \multirow{2}{*}{62} \\
\hline $16 S$ rRNA-R & ATTACCGCGGCTGCTGG & \\
\hline
\end{tabular}

505

506 
Table 2. Inhibitory effect of tested drugs on growth of strain OTC-16

\begin{tabular}{|c|c|c|c|c|c|}
\hline $\begin{array}{l}\text { Antibiotic } \\
\text { categories }\end{array}$ & $\begin{array}{l}\text { Antibiotics } \\
\text { ( } \mu \text { g per disc) }\end{array}$ & $\begin{array}{l}\text { Test } \\
\text { effect }\end{array}$ & $\begin{array}{l}\text { Antibiotic } \\
\text { categories }\end{array}$ & $\begin{array}{l}\text { Antibiotics } \\
\text { ( } \mu \text { g per disc) }\end{array}$ & $\begin{array}{l}\text { Test } \\
\text { effect }\end{array}$ \\
\hline \multirow{4}{*}{ Tetracyclines } & \multirow{4}{*}{$\begin{array}{l}\text { Chlorotetracycline(30) } \\
\text { Doxycycline(30) } \\
\text { Oxytetracycline(30) } \\
\text { Minocycline(30) } \\
\text { Tetracycline(30) }\end{array}$} & \multirow{4}{*}{$\begin{array}{l}+ \\
+ \\
- \\
+ \\
-\end{array}$} & \multirow[t]{2}{*}{ Polypeptide } & $\begin{array}{l}\text { Polymyxin(300) } \\
\text { Bacitracin(0.04) } \\
\text { Vancomycin(30) }\end{array}$ & \multirow{3}{*}{$\begin{array}{l}+- \\
- \\
+- \\
- \\
\end{array}$} \\
\hline & & & & & \\
\hline & & & Polyene & Nystatin(100) & \\
\hline & & & \multirow{6}{*}{ Quinolones } & $\begin{array}{l}\text { Ciprofloxacin(5) } \\
\text { Ciprofloracin(5) }\end{array}$ & $\begin{array}{l}+ \\
+\end{array}$ \\
\hline \multirow{5}{*}{ Sulfonamides } & Sulfadimethoxine(100) & - & & Ofloxacin(5) & + \\
\hline & Sulfamethoxazole(30) & - & & Enoxacin(10) & + \\
\hline & Sulfadimethazine(300) & - & & Enrofloxacin(10) & + \\
\hline & $\begin{array}{l}\text { Sulfamonomethoxine } \\
\text { (30) }\end{array}$ & - & & Norfloxacin(10) & + \\
\hline & Cotrimoxazole(23.75) & - & & Nalidixic acid(30) & - \\
\hline Macrolides & $\begin{array}{l}\text { Erythromycin(15) } \\
\text { Midecamycin(30) }\end{array}$ & $\begin{array}{l}+ \\
+ \\
\end{array}$ & Lincosamides & $\begin{array}{l}\text { Clindamycin(2) } \\
\text { Lincomycin(20) }\end{array}$ & $\begin{array}{l}+ \\
+- \\
\end{array}$ \\
\hline \multirow{4}{*}{$\begin{array}{l}\text { Aminoglycosid } \\
\text { es }\end{array}$} & \multirow{4}{*}{$\begin{array}{l}\text { Gentamicin(10) } \\
\text { Amikacin(30) } \\
\text { Tobramycin(10) } \\
\text { Neomycin(30) } \\
\text { Kanamycin(30) } \\
\text { Kanamycin sulfate(30) } \\
\text { Streptomycin(10) } \\
\text { Streptomycin } \\
\text { sulphate(10) }\end{array}$} & \multirow{4}{*}{$\begin{array}{l}+ \\
+ \\
+- \\
+ \\
+- \\
+- \\
- \\
-\end{array}$} & Penicillins & $\begin{array}{l}\text { Piperacillin(100) } \\
\text { Ampicillin(20) } \\
\text { Amoxicillin(20) } \\
\text { Penicillin(20) }\end{array}$ & $\begin{array}{l}+ \\
+ \\
+ \\
+\end{array}$ \\
\hline & & & Chloramphenicols & Chloramphenicol(30) & +- \\
\hline & & & Nitrofurans & $\begin{array}{l}\text { Macrodantin(300) } \\
\text { Furazolidone(300) }\end{array}$ & $\begin{array}{l}+- \\
-\end{array}$ \\
\hline & & & Glycopeptides & Vancomycin(30) & + \\
\hline \multirow{7}{*}{ Cephalosporin } & Cefotaxime(30) & + & \multirow{4}{*}{ Others } & Rifampicin(5) & + \\
\hline & Aventiamycin IV(30) & + & & & \\
\hline & Cefalexin(30) & + & & $\begin{array}{l}\text { Isopropyl-b-D-thiogala } \\
\text { ctoside }(0.01 \mathrm{~g} / \mathrm{ml})\end{array}$ & - \\
\hline & Cefazolin $(30)$ & + & & Metronidazole(5) & - \\
\hline & \multirow{3}{*}{$\begin{array}{l}\text { Ceftriaxone(30) } \\
\text { Mefoxin(30) } \\
\text { Cefoperazone (75) }\end{array}$} & + & & & \\
\hline & & + & & & \\
\hline & & + & & & \\
\hline
\end{tabular}

Note: +: Strain OTC-16 is high sensitive to the drugs (Diameter of bacteriostatic circle $\geq 1.3 \mathrm{~cm}$ ); -: strain OTC-16 is high resistant to the drugs (No bacteriostatic circles were observed); +-: strain OTC-16 is medium resistant to the drugs (Diameter of bacteriostatic circle $<1.3 \mathrm{~cm}$ ). 
Table 3. ARGs information of strain OTC-16

\begin{tabular}{|c|c|c|c|c|c|}
\hline Location & Gene_id & Subject_id & $\begin{array}{l}\text { Gene_ } \\
\text { type }\end{array}$ & $\begin{array}{l}\text { Antibiotic_ } \\
\text { resistance }\end{array}$ & $\begin{array}{l}\text { Original_ } \\
\text { Resistance } \\
\text { _Type }\end{array}$ \\
\hline Chromosome & ZAF-05GL000241 & ardb_2199 & tetv & tetracycline & tet_efflux \\
\hline Chromosome & ZAF-05GL000615 & ardb_115 & vanre & vancomycin & vane \\
\hline Chromosome & ZAF-05GL000913 & ardb_1951 & cml_e6 & chloramphenicol & $\mathrm{cml}$ \\
\hline Chromosome & ZAF-05GL001175 & ardb_2604 & cara & $\begin{array}{l}\text { lincosamide,streptogram } \\
\text { macrolide }\end{array}$ & mls_abc \\
\hline Chromosome & ZAF-05GL001392 & ardb_2322 & bcra & bacitracin & bcr \\
\hline Chromosome & ZAF-05GL001549 & ardb_2778 & catb3 & chloramphenicol & catb \\
\hline Chromosome & ZAF-05GL002124 & ardb_2395 & vanrc & vancomycin & vanc \\
\hline Chromosome & ZAF-05GL003407 & ardb_2606 & bcra & bacitracin & bcr \\
\hline Plasmid1 & ZAF-05GL003435 & ardb_598 & tet33 & tetracycline & tet_efflux \\
\hline Plasmid1 & ZAF-05GL003441 & ardb_571 & sull & sulfonamide & sul \\
\hline Plasmid1 & ZAF-05GL003442 & ardb_2203 & ant $2 i a$ & $\begin{array}{l}\text { tobramycin,kanamycin, } \\
\text { sisomicin,dibekacin, } \\
\text { gentamicin }\end{array}$ & ant \\
\hline Plasmid1 & ZAF-05GL003445 & ardb_598 & tet33 & tetracycline & tet_efflux \\
\hline Plasmid1 & ZAF-05GL003450 & ardb_571 & sull & sulfonamide & sul \\
\hline Plasmid1 & ZAF-05GL003451 & ardb_2203 & ant $2 i a$ & $\begin{array}{l}\text { tobramycin,kanamycin, } \\
\text { sisomicin,dibekacin, } \\
\text { gentamicin }\end{array}$ & ant \\
\hline Plasmid1 & ZAF-05GL003527 & ardb_1888 & cml_e8 & chloramphenicol & $\mathrm{cml}$ \\
\hline Plasmid2 & ZAF-05GL003540 & ardb_598 & tet 33 & tetracycline & tet_efflux \\
\hline Plasmid2 & ZAF-05GL003544 & ardb_571 & sull & sulfonamide & sul \\
\hline Plasmid2 & ZAF-05GL003545 & ardb_2200 & ant $2 i a$ & $\begin{array}{l}\text { tobramycin,kanamycin, } \\
\text { sisomicin,dibekacin, } \\
\text { gentamicin }\end{array}$ & ant \\
\hline Plasmid2 & ZAF-05GL003548 & ardb_598 & tet33 & tetracycline & tet_efflux \\
\hline Plasmid2 & ZAF-05GL003552 & ardb_571 & sull & sulfonamide & sul \\
\hline Plasmid2 & ZAF-05GL003553 & ardb_2200 & ant $2 i a$ & $\begin{array}{l}\text { tobramycin,kanamycin, } \\
\text { sisomicin,dibekacin, } \\
\text { gentamicin }\end{array}$ & ant \\
\hline Plasmid2 & ZAF-05GL003556 & ardb_598 & tet33 & tetracycline & tet_efflux \\
\hline Plasmid2 & ZAF-05GL003560 & ardb_571 & sull & sulfonamide & sul \\
\hline
\end{tabular}




\section{Figures}

a
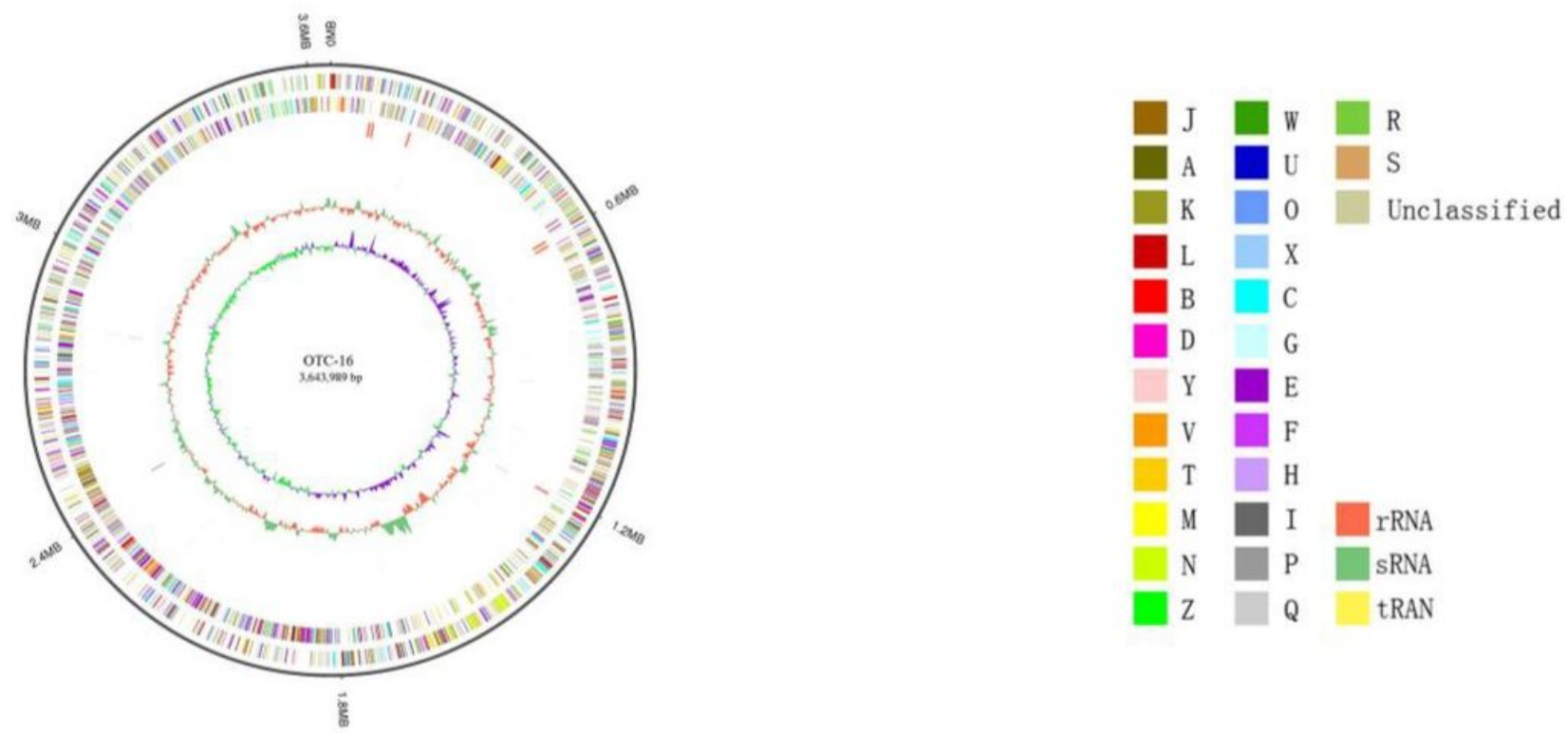

b
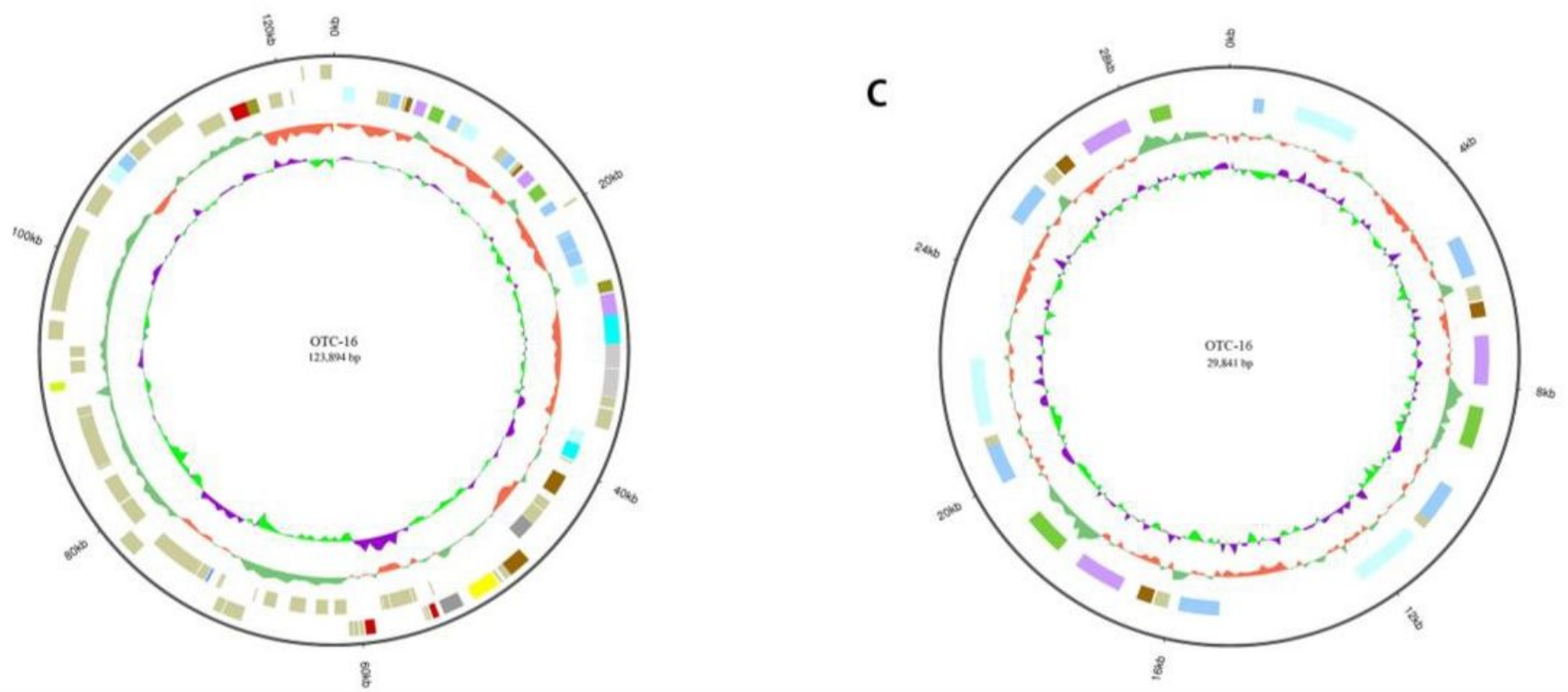

Figure 1

map of the chromosome (a), plasmid1 (b) and plasmid2 (c) of strain OTC-16. From inner to outer: Genome size; Forward Strand Gene(colored by COG classification)区Reverse Strand Gene(colored by COG classification) $₫$ Forward Strand ncRNA囚Reverse Strand ncRNA; Repeat gene; G+C content; GCSKEW (calculated as $(\mathrm{G}-\mathrm{C}) /(\mathrm{G}+\mathrm{C})$; green/purple peaks out/inside the circle indicate values higher or lower than 1 , respectively. 


\section{KEGG Pathway Classification}

$$
\begin{array}{r}
\text { Cell growth and death- } \\
\text { Cell motility- } \\
\text { Cellular community - prokaryotes - } \\
\text { Transport and catabolism- } \\
\text { Membrane transport - } \\
\text { Signal transduction- }
\end{array}
$$

Folding, sorting and degradation-

Replication and repair -

Transcription -

Translation -

Drug resistance: AntimicrobialInfectious diseases: BacterialInfectious diseases: Parasitic-

Amino acid metabolism -

Biosynthesis of other secondary metabolites.

Carbohydrate metabolism -

Energy metabolism -

Global and overview maps -

Glycan biosynthesis and metabolism -

Lipid metabolism -

Metabolism of cofactors and vitamins -

Metabolism of other amino acids -

Metabolism of terpenoids and polyketides -

Nucleotide metabolism -

Xenobiotics biodegradation and metabolism -

Aging -

Digestive system -

Endocrine system -

Environmental adaptation-

Immune system -

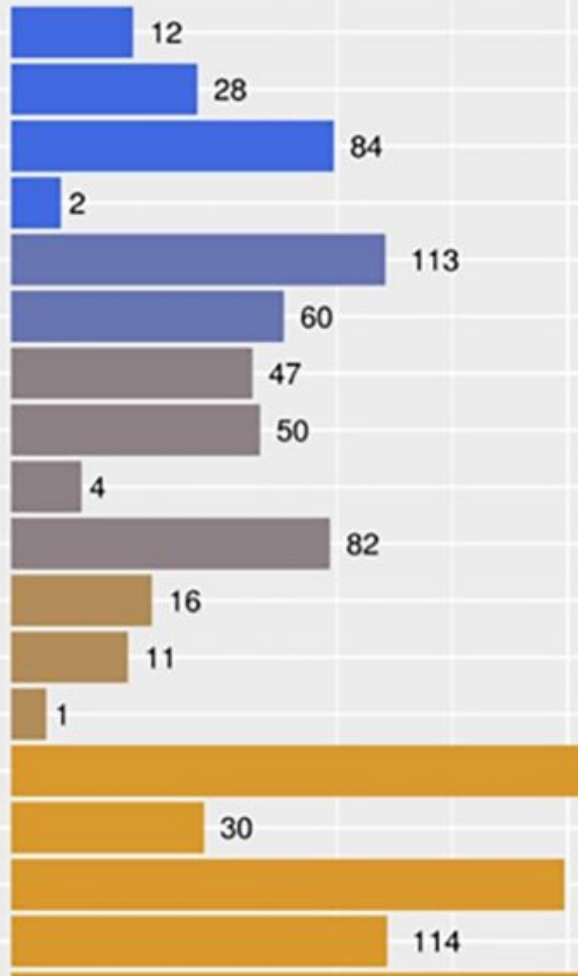

269

247

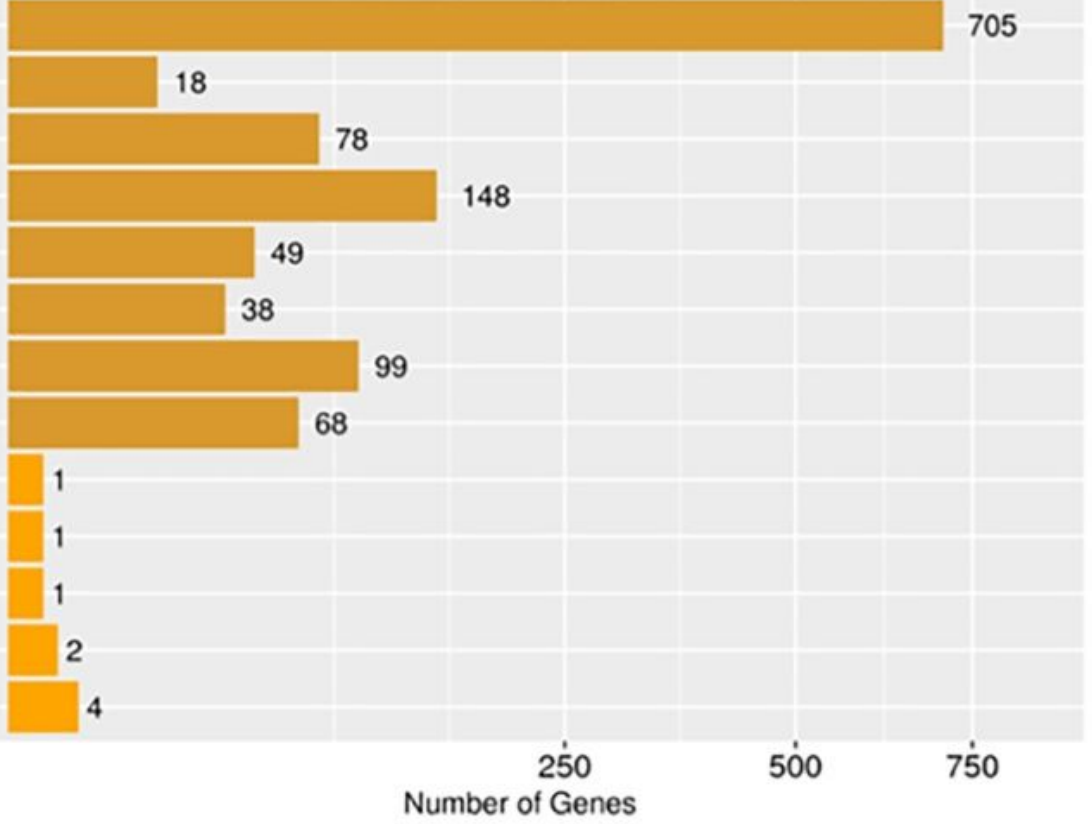

\section{Figure 2}

KEGG function annotation distribution map of strain OTC-16. 

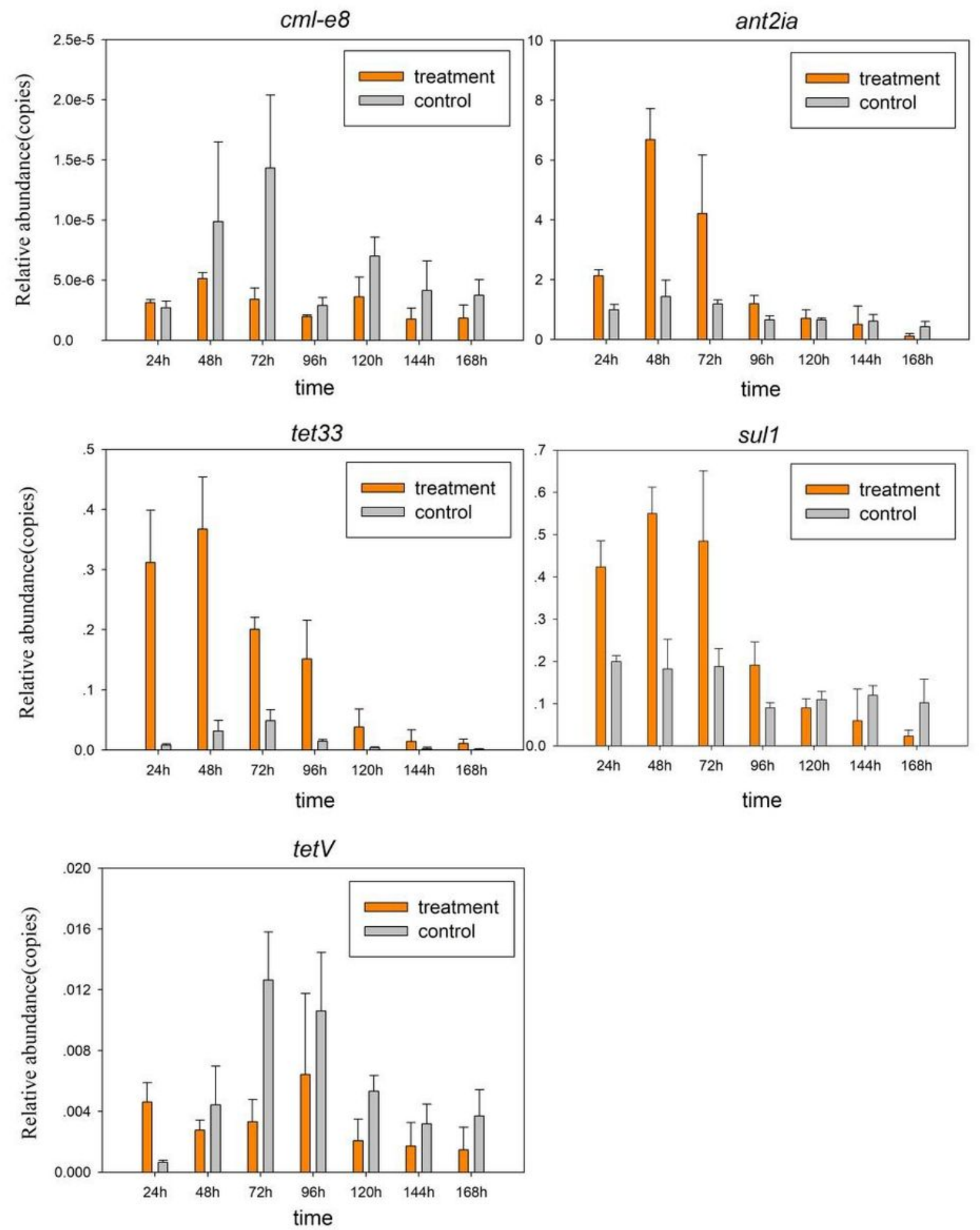

Figure 3

Relative abundance of resistance gene expression at 24-168 $\mathrm{h}$. 

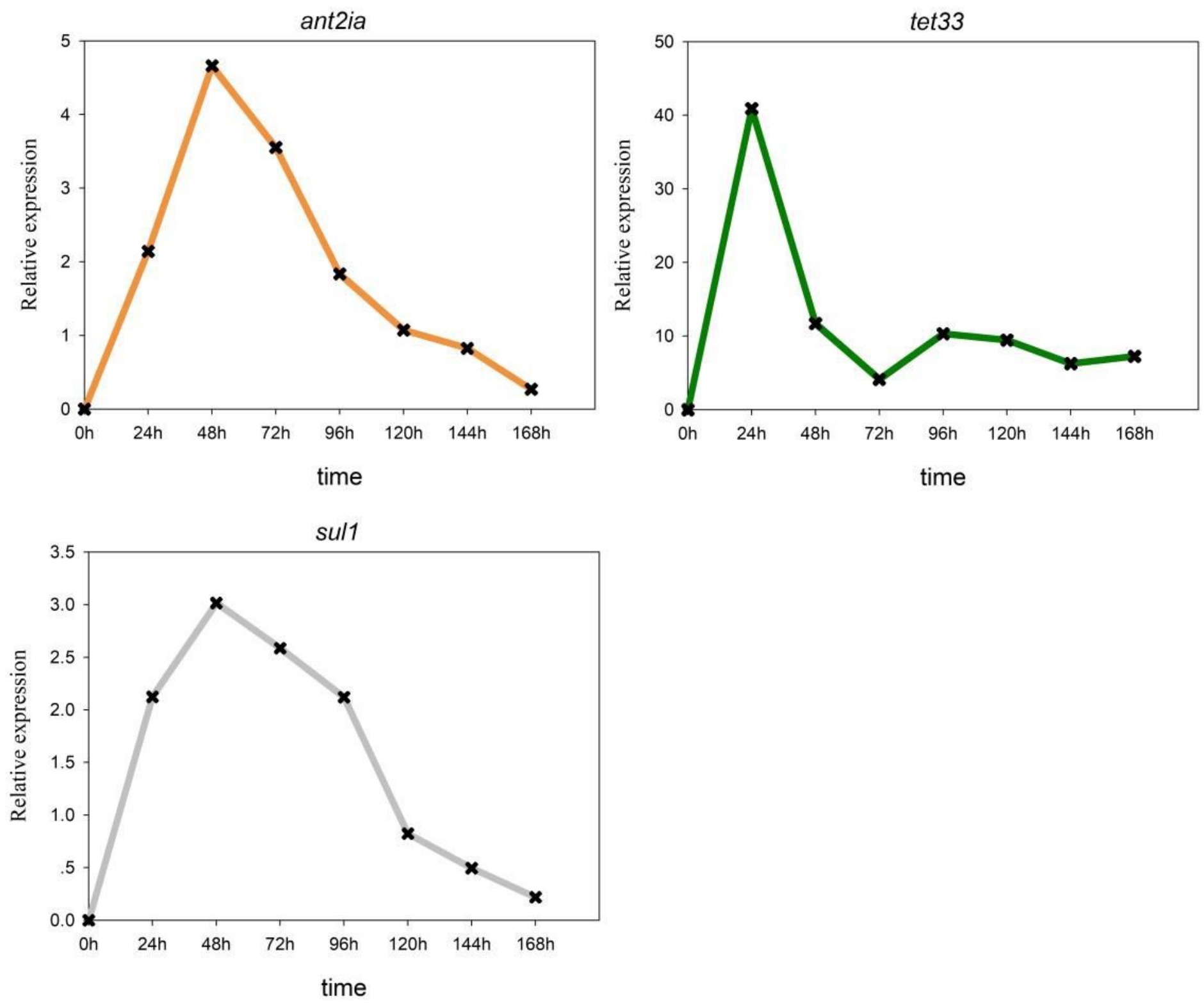

Figure 4

The expression levels of resistance genes tet33, sul1, and ant2ia changed at 24-168 $\mathrm{h}$. 

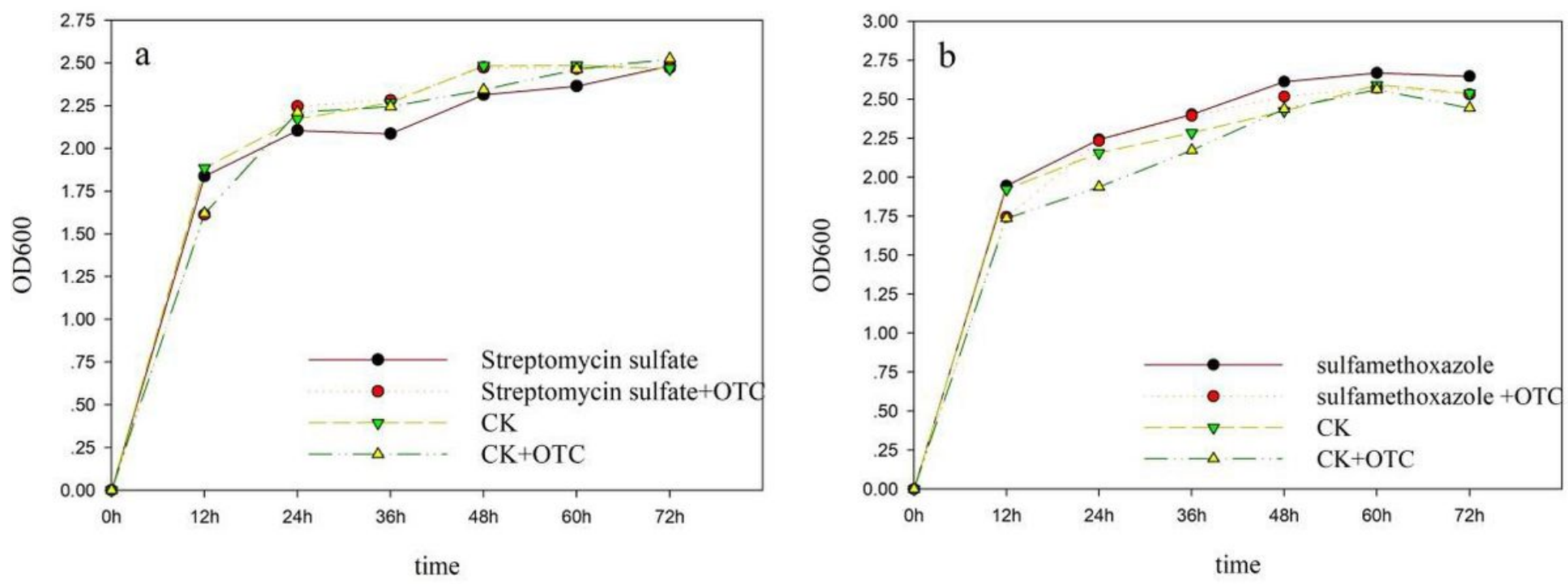

Figure 5

Effect of streptomycin sulfate(a) and sulfamethoxazole(b) on the growth of strain OTC-16.

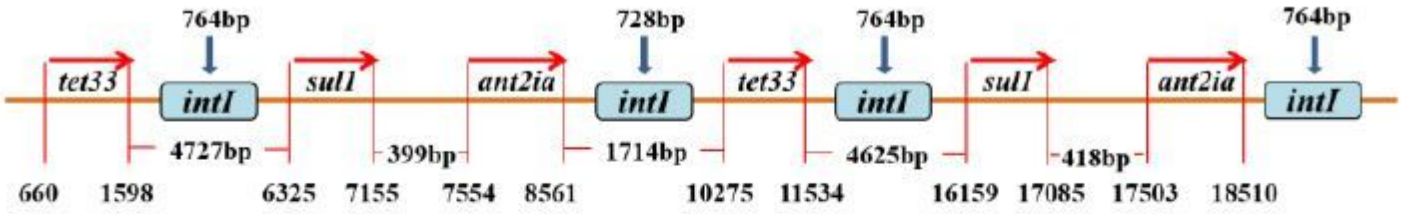

Plasmid1

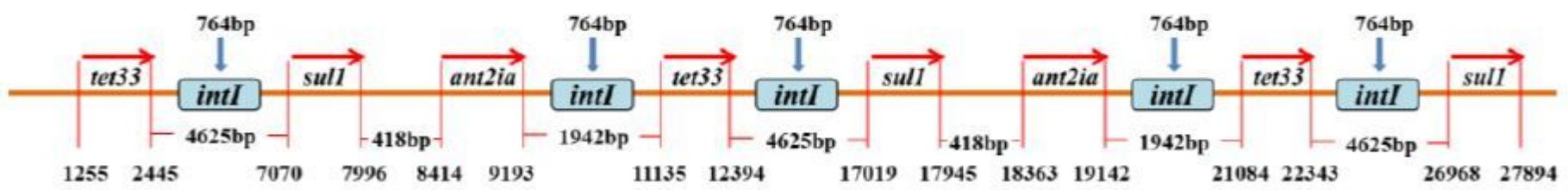

Plasmid2

\section{Figure 6}

The sites of gene sul1, tet33 and ant2ia on plasmid 1 and plasmid 2.

\section{Supplementary Files}

This is a list of supplementary files associated with this preprint. Click to download.

- Supplementaryinformation.docx 
- FigureS1.zip

- graphcalabstract.zip 